Baazaoui, H. (2020). For a new method of calculating the disclosure index. Copernican Journal of Finance \& Accounting, 9(2), 9-24. http://dx.doi.org/10.12775/CJFA.2020.005

\author{
Hedi BaAzaoui* \\ University of Kairouan
}

\title{
FOR A NEW METHOD OF CALCULATING THE DISCLOSURE INDEX
}

Keywords: disclosure index, disclosure, IAS/IFRS information.

J E L Classification: M41.

Abstract: In this paper, we have proposed a new method for calculating the disclosure index, which consists of calculating the basic score by accounting standard or category of information and determining the overall disclosure index, which is the average of the elementary scores. Through two French and Canadian samples, we found significant differences between the mandatory, voluntary and total disclosure indices calculated using the proposed method and the current method.

\section{INTRODUCTION}

Disclosure of information is perhaps the cornerstone of corporate financial reporting. It is thanks to the published information that the company can maintain business relations with its various partners. Financial information is of interest to market participants (companies, investors, bankers, auditors, etc.), citizens, employees and the state, and it is therefore insufficient to see accounting standards regardless of the socio-economic context (Palea, 2015).

Date of submission: April 7, 2020; date of acceptance: May 9, 2020.

* Contact information: hedi_baazaoui@yahoo.com, Higher Institute of Computer Sciences and Management, University of Kairouan, Kairouan, Tunisia, phone: 0021698 5960 54; ORCID ID: https://orcid.org/0000-0001-6880-1822. 
Disclosure of information has been the subject of much research with the primary purpose of finding the determinants of this disclosure. In developed countries, research studies have tried to identify the explanatory variables of voluntary disclosure, and in developing countries, they have tried to identify the explanatory variables of mandatory disclosure since in the last type of countries the companies adopt an information retention policy and tend not to comply with the regulations governing the disclosure of information.

Whether mandatory disclosure or voluntary disclosure, disclosure studies calculated the disclosure index as the sum of published items divided by the total items that could be disclosed without distinction between categories of information for voluntary disclosure (general information, financial information, operational information, etc.) and between items within the accounting standard for mandatory disclosure and implicitly assumes that all categories of information for voluntary disclosure and all standards for disclosure mandatory disclosure are equally important.

The interest of this research is to propose a new method of calculating the index of disclosure. It should be noted that disclosure studies suffer from a major limitation by adopting an overall score. They implicitly assume the superiority of certain standards or categories of information over others since the number of items in the standards varies considerably from one standard to another.

In our study, we calculate the standard disclosure score by standard implicitly assuming that international standards have the same importance and the overall disclosure score is none other than the simple arithmetic mean of the individual disclosure scores.

In what follows, we will present the literature dealing with the disclosure index, the methodology, the results and the conclusion.

\section{REVIEW OF LITERATURE}

"The disclosure literature has shown that a high quality of public disclosure reduces the asymmetry of information and therefore increases the liquidity of equities" (Alves, Canadas \& Rodrigues, 2015, p. 67). For their part, Avallone and Quagli (2015) found that the manipulation of the results through the test of depreciation carried out on the goodwill should encourage the standardization bodies to demand more disclosure on how to determine the recoverable 
amount in order to minimize the effect of managerial opportunism. In addition, "the quality of the disclosed accounting information is affected by the applicable accounting framework, the political and legal systems of the country and the attitudes and motivations of the managers in terms of financial communication" (Păúcan, 2015, p. 586).

Customers want to know if the company is able to secure their supplies on a continuous basis so they need to have a clear idea of their financial health. Suppliers need to know if the company is able to meet its financial commitments. They need to have an idea about the solvency and liquidity of the company with whom they have business relationships. The state needs financial information to properly develop economic aggregates and to have an idea about the creation and distribution of wealth to put in place fiscal, financial and legal regulations. Holders of capital seek profitable investments. In order to make investment or credit decisions, these investors (investors and lenders) need financial information to evaluate, compare and predict the company's profitability, solvency and financial position liquidity.

Thus, the absence of information on the operations carried out implies that the managers manage the affairs in their interests. This means a lack of compatibility of the owners' objectives with those of the managers. Managers act opportunistically, therefore, in the absence of a protection mechanism, potential shareholders buy the shares at a reduced price and the lenders, in the presence of a high risk, demand a high interest.

Companies that do not publish information are penalized by high capital costs. The company is in a better position to determine the nature of the information to be produced and to increase the trust of funders. Imposing regulations may restrict the choice of accounting methods (for example, imposing a single depreciation method) and therefore the efficiency sought in negotiating contracts to reduce agency costs may not be achieved.

The information must be produced to minimize the cost of capital and increase the value of the business. So provide the information until its marginal cost equals its additional benefit.

Environments differ from country to country and therefore disclosure and reporting standards and practices will necessarily diversify. Measurement and disclosure practices are strongly influenced by environmental factors in the country. The influence of environmental factors on the quality and content of information disclosure has been defended by the theory of environmental determinism. 
The level of economic and social development of the country is a determining factor of the economic and social disclosure made by the firm. The study of Xiao, Gao, Heravi and Cheung (2005) showed that British firms disclose more economic and social information than Hong Kong firms, "because of the different pressures exerted and the increased demands for disclosure likely to expose the firm to the political costs and threats of legitimacy "(Xiao et al., 2005, p. 219).

Chan, Hsieh, Lee and Yueh (2015) have shown that the adoption of international IAS/IFRS standards has improved the comparability of financial statements rather than accounting quality. In addition, it has reduced the asymmetry of information for foreign banks, which are encouraged to make cross-border loans. However, Barneto and Ouvrard (2015) have shown the limits of IAS/ IFRS standards by noting that the disclosure of segment information contained in the notes to the financial statements as provided by IAS14 and IFRS8 does not improve understanding business plans prepared on the basis of the indicators for the statement of cash flows provided for in IAS7.

The non-adoption of certain national standards reflects according to Ding, Jeanjean and Stolowy (2005) the state of the economy rather than the national culture. In fact, the adoption of the international benchmark is decreed by international institutions (the World Bank, the International Monetary Fund, the International Organization of Securities Commissions, the IFAC, capital markets, international audit firms Big4 and the IASB) (Uyar \& Güngörmüs, 2013) rather than by national economic needs.

Similarly, Nnadi and Soobaroyen (2015) found that, despite the fact that a number of empirical studies have shown that the adoption of IAS/IFRS standards promotes foreign direct investment in developing countries, the full adoption of IAS/IFRS has a negative impact on net foreign direct investment in African countries. According to these authors, foreign investors seem to be affected by fundamental institutional structures such as the rule of law, the legal system and the level of corruption rather than by the adoption of IAS/IFRS.

Eiler, Miranda-Lopez and Tama-Sweet (2015) found that the information content of published profits has increased in the new information environment (adoption of IAS/IFRS and financial market reform).

Perera and Chand (2015) argued that previous studies have revealed several functional complications towards convergence with international standards. In the same vein, "The difficulties of implementing an international standard due to the lack of widespread technical expertise in the accounting 
environment are also a concern" (Perera \& Chand, 2015, p. 173). The educational resource provides a beneficial learning opportunity in the field of international accounting (Teuteberg, Voll \& Zülch, 2016, p. 14). The case study helps students gain an idea of how international standards are applied by accountants in bankruptcy (Churyk, Yu, Gross \& Stoettner, 2015) for example. Chen, Deng, Gupta and Sami (2015) showed that the application of IAS/IFRS following the elimination of reconciliations imposed by the American Securities and Exchange Committee in 2007 reduced the asymmetry of information on the financial market measured by the bid-ask spread.

The economic consequences of applying IAS/IFRS are significant. Along these lines, Baik, Cho, Choi and Lee (2016) examined the determinants and economic consequences of taking interest payment into account in operating cash flows. They showed that "distressed companies, companies with high interest payments, companies with majority stake in banks and listed companies tend to change interest payments from the operating state to the statement of financing flows, thereby increasing the total amount of operating cash flows" (Baik et al., 2016, p. 1).

Pierk and Weil (2016) have shown that companies early adopt new regulations that tend to improve the amount of revenue and financial performance. According to De Simone (2016), tax incentives affect the choice of accounting framework in countries that allow but do not require the application of IAS/IFRS standards for individual accounts and cross-border investments through the transfer of income through the transfer price mechanism are motivated by tax reasons and not by the adoption or not of IAS/IFRS standards.

Pressure groups in the standardization process have been identified by Bamber and McMeeking (2016). They have shown that the stakeholders (preparers, users and professional and regulatory bodies) have more influence than the accounting bodies on the process of standardization and amendments to international accounting standards and more precisely on discussions and debates taking place under the accounting standard relating to IFRS7 financial instruments from the exposure draft until its final approval. In addition, they found that the IASB reacted much less to proposals from the United Kingdom than to comments from the United States.

Environmental factors are advanced in the literature as major determinants of information disclosure, regardless of its nature, quantity and quality. In this sense, Joliet and Muller (2016) have identified attractive areas of foreign direct investment which are peaceful Asia and the United Kingdom but not Lat- 
in America, based on the informational content of the communication of profits and sector information and Elshandidy, Fraser and Hussainey (2015) have shown that both mandatory and voluntary risk disclosure presents a high level for German firms compared to British and American firms. They also showed that disclosure varies according to the specific characteristics of the firm, the national characteristics of the country (legal system and cultural values) and the systematic risk.

For their part, Lin and Nienhaus (2015) showed that German firms were able to reduce the systematic risk and the cost of capital after the change of the German or American accounting standards by the international IAS/IFRS standards requiring more disclosure and Wilford (2016) showed that foreign companies submitting IAS/IFRS financial statements to the Securities and Exchange Committee report fewer weaknesses in the internal control system when they come from countries with high regulations and report more weaknesses in the internal control system when they come from countries with weak internal control system regulations.

Ghio and Verona (2015, p. 121) found that the political, cultural and economic dimensions are behind the choice of the process of convergence towards international IAS/IFRS standards between a simple imitation (the case of Russia and Brazil) and the actual translation with certain modifications (the case of China and India) and Cerbioni, Fabrizi and Parbonetti (2015, p. 174) have shown that the financial crisis has shown that the accounting rules have not kept pace complex developments in financial transactions such as securitization and have given managers a lot of leeway.

The application of international standards in complex social contexts is facing resistance from their users in seeking to guarantee their interests, thus demanding on the part of the global preparer of these standards the IASB to be more vigilant in resolving this type of challenge (Maroun \& Zijl, 2016). Accounting tends towards the adoption of an integral value approach, this means that the measurement of the economic value of an accounting item can influence the perception of the cultural value of the item in question (Ellwood \& Greenwood, 2016).

Measurement and disclosure practices are strongly influenced by environmental factors in the country. Xiao, Yang and Chow (2004) have shown that country-specific country factors are determinants of the explanation of voluntary disclosure and the extent of disclosure in content and format. Thus, audit quality, foreign equity participation, different classes of shares and regulations 
are specific variables explaining voluntary disclosure as well as the extent of disclosure on the internet.

Studies have addressed the impact of the firm's and society's characteristics in general on disclosure. These characteristics include "size, listing status, performance, type of industry and nature of audit. The characteristics of the country are the size of the financial market, the degree of economic development, the type of the economy, the activity of the financial market, the dispersion of shares and the culture" (Street \& Bryant, 2009, p. 307).

Previous studies have shown the limitations of the firm's characteristics in explaining the disclosure of information. They have incorporated cultural dimensions into their empirical validation model because they consider that the firm's leaders are dominated by cultural values and norms. Two firms with the same characteristics but belonging to two countries of different cultures do not disclose the same quantity or the same quality of information, which shows the importance of the effect of cultural dimensions on the disclosure of information. In addition, research recommends the consideration of economic factors that are external and exogenous to the firm.

Disclosure research can be divided into three categories. Those interested in the effect of the cultural, economic, legal, tax and social dimensions (category 1), those interested in the effect of the characteristics of the firm (category 2) and those interested in the effect of governance mechanisms (category 3).

Disclosure of information is considered in terms of quality and quantity. Two measurement methods are applied: content analysis and calculation of disclosure indices (Joseph \& Taplin, 2011). According to these authors, the abundance of disclosure refers to the analysis of the content and volume of the disclosure and the occurrence of the disclosure refers to the disclosure index. The abundance of the disclosure takes into account the number of words, sentences, lines, pages, etc. and the occurrence of the disclosure takes into account the items disclosed to calculate the disclosure index or score.

An abundant literature has dealt with the disclosure of information by companies and mainly voluntary disclosure. Most disclosure work considers a particular determinant of disclosure (firm characteristics, governance mechanisms, etc.) or studies the impact of financial market disclosure on firm valuation or risk assessment or costing of capital.

Debates have focused on the content of the published information. Some have argued that the disclosure of non-mandatory information may be against 
the interest of society (negative externality) and others find in this type of disclosure benefits for society (positive externality).

According to Verrecchia (1983, p. 191), disclosure is measured in terms of the nature of the information proprietary to the firm. Firms operating in a fiercely competitive industry consider that public disclosure represents a potential cost since it can be exploited by competitors and firms operating in a low-cost sector do not bear the cost associated with public disclosure. This is why managers are in a better position to determine the nature and quality of the information to be disclosed.

Indeed, financial communication is a strategic and complex decision emanating from the people who constitute corporate governance (La Bruslerie \& Gabteni, 2014).

\section{THE RESEARCH METHODOLOGY AND THE COURSE OF THE RESEARCH PROCESS}

We will study the disclosure of mandatory and voluntary information since the adoption of IAS/ IFRS does not necessarily reflect their application and empirically assess the degree of application by category of country given the variability of application of the international standard.

Disclosure can be voluntary or mandatory. We have chosen to work on full disclosure which includes both voluntary and mandatory disclosure because any information can be useful to a particular user. It is therefore recommended to disclose as much information as possible.

Previous studies have used different categories of voluntary information to calculate the voluntary disclosure index. In this study, we rely on IAS/IFRS standards to identify mandatory or voluntary disclosure items.

Our goal is to show the utility of applying the new method since it considers that all standards and all categories of information have the same importance. Thus, the significance of the difference in the disclosure indices computed according to two methods must be tested. The first method is to calculate the score by accounting standard and to average the basic disclosure scores. The second method is to relate the sum of the items disclosed to the sum of items that may be disclosed.

It should also be noted that disclosure studies suffer from a major limitation in adopting an overall score. They implicitly assume the superiority of certain standards over others since the number of items contained in the stand- 
ards varies considerably from one standard to another (IAS1 (79 items), IAS2 (8 items), IAS23 (2 items), IFRS7 (115 items), etc.). In our study, we calculate the standard-by-standard disclosure score implicitly assuming that international standards are of equal importance and the overall disclosure score is none other than the simple arithmetic mean of the individual disclosure scores.

The method of calculating the average of elementary indices gives the same importance to all standards and therefore it favors elementary disclosure by accounting standard. On the other hand, the method of calculating the disclosure index by the ratio between the disclosed items and the applicable items attaches importance to global disclosure and neglects the usefulness of basic disclosure attached to the accounting standard. The disclosure policy adopted by companies must be understood in depth and evaluated in detail if we want to objectively assess the degree of application of IAS/IFRS standards.

To test the significance of the difference in disclosure scores, we will compute the mandatory, voluntary, and total disclosure scores for both methods.

Table 1. Calculation of index disclosure

\begin{tabular}{|c|c|c|}
\hline & Proposed method (method1) & Actual method (method2) \\
\hline Elementary disclosure score & $\begin{array}{l}\mathrm{E}_{\mathrm{ds}}=\sum_{1}^{p} \frac{I_{i}}{p} \\
\text { Where li: item i that has } 1 \text { if it is } \\
\text { disclosed, } 0 \text { otherwise, and } \mathrm{p} \text { : the } \\
\text { number of applicable items of the } \\
\text { information category or of the } \\
\text { standard. }\end{array}$ & - \\
\hline Disclosure index & $\begin{array}{l}\mathrm{D}_{\mathrm{i}}=\sum_{1}^{n} \frac{E_{d s}}{n} \\
\text { Where } \mathrm{E}_{\mathrm{ds}}: \text { the elementary disclo- } \\
\text { sure score and } \mathrm{n} \text { : the number of the } \\
\text { information categories or of the } \\
\text { standards. }\end{array}$ & $\begin{array}{l}\mathrm{D}_{\mathrm{i}}=\sum_{1}^{k} \frac{I_{i}}{k} \\
\text { Where li: item i that has } 1 \text { if it is } \\
\text { disclosed, } 0 \text { otherwise, and } \mathrm{k} \text { : the } \\
\text { number of applicable items for all } \\
\text { information categories or all stan- } \\
\text { dards. }\end{array}$ \\
\hline
\end{tabular}

S o u r c e : calculation of disclosure index: prepared in this paper.

Given the widespread adoption of international IAS/IFRS standards, we have chosen to study disclosure of information (IAS/IFRS). We have chosen to work on IAS/IFRS international financial reporting standards. 
Our database is imported from the study of Baazaoui, Sahnoun and Zaraï (2015). We selected both French and Canadian samples. The study period is limited to fiscal year 2013, the most recent fiscal year when data was collected. Since the principle of permanence of the methods requires the application of the same methods of measurement and presentation over time, unless the change is made by a new standard or if there is a structural change in the operation, it is so it's useless to work on several exercises. In all cases, in the event of a change in accounting method, the Company is required to disclose in the notes to the financial statements the nature, the reasons and the financial impact of this change.

Our study covered 35 French companies listed on CAC40 and 36 Canadian companies listed on ${ }^{\wedge}$ TX60.

The samples in the study are as follows:

Table 2. Samples of the study

\begin{tabular}{|l|c|c|c|}
\hline \hline & French sample & Canadian sample & Overall sample \\
\hline \hline Initial sample & 40 & 60 & 100 \\
\hline Financial Institutions & 4 & 10 & 14 \\
\hline Subsidiary of foreign parent & 1 & 1 & 3 \\
\hline $\begin{array}{l}\text { Companies presenting their financial state- } \\
\text { ments according to US GAAP or national GAAP }\end{array}$ & 35 & 36 & 71 \\
\hline Total & & 36 \\
\hline
\end{tabular}

S o u r c e : samples of the study: Baazaoui et al. (2015).

\section{RESULTS OF RESEARCH PROCESS}

For the first method, which consists in calculating the disclosure index based on the average of the elementary disclosure scores, the various disclosures are marked by the index 1: mandatory disclosue1, voluntary disclosure1, total disclosure1.

For the second method, which consists in calculating the disclosure index based on the ratio between the items disclosed and the total items, the various disclosures are marked by the index 2: mandatory disclosure2, voluntary disclosure2, total disclosure2.

The characteristics of the variables in the study are as follows: 
Table 3. Variables characteristics

\begin{tabular}{|c|c|c|c|c|c|c|c|}
\hline Variable & minimum & maximum & mean & $\begin{array}{l}\text { standard } \\
\text { deviation }\end{array}$ & skewness & kurtosis & $\begin{array}{l}\text { Prob (Ja- } \\
\text { rque-Bera) }\end{array}$ \\
\hline \multicolumn{8}{|l|}{ French sample } \\
\hline Mandatory disclosure1 & 0.54 & 0.79 & 0.65 & 0.06 & 0.49 & 2.63 & 0.45 \\
\hline Mandatory disclosure2 & 0.64 & 0.90 & 0.73 & 0.06 & 1.11 & 3.91 & 0.02 \\
\hline Voluntary disclosure1 & 0.11 & 0.67 & 0.39 & 0.19 & -0.08 & 1.70 & 0.28 \\
\hline Voluntary disclosure2 & 0.13 & 0.60 & 0.37 & 0.15 & -0.01 & 2.09 & 0.55 \\
\hline Total disclosure1 & 0.48 & 0.77 & 0.60 & 0.08 & 0.47 & 2.32 & 0.37 \\
\hline Total disclosure2 & 0.62 & 0.89 & 0.71 & 0.06 & 1.10 & 3.95 & 0.02 \\
\hline \multicolumn{8}{|l|}{ Canadian sample } \\
\hline Mandatory disclosure1 & 0.49 & 0.85 & 0.72 & 0.07 & -0.44 & 4.07 & 0.23 \\
\hline Mandatory disclosure2 & 0.69 & 0.90 & 0.81 & 0.05 & -0.84 & 3.38 & 0.11 \\
\hline Voluntary disclosure1 & 0.00 & 0.79 & 0.56 & 0.15 & -1.74 & 6.98 & 0.00 \\
\hline Voluntary disclosure2 & 0.00 & 0.80 & 0.50 & 0.13 & -1.60 & 8.71 & 0.00 \\
\hline Total disclosure1 & 0.39 & 0.84 & 0.69 & 0.08 & -1.08 & 6.09 & 0.00 \\
\hline Total disclosure2 & 0.68 & 0.89 & 0.80 & 0.05 & -0.82 & 3.31 & 0.13 \\
\hline \multicolumn{8}{|l|}{ Overall sample } \\
\hline Mandatory disclosure1 & 0.49 & 0.85 & 0.68 & 0.08 & 0.10 & 2.73 & 0.85 \\
\hline Mandatory disclosure2 & 0.64 & 0.90 & 0.77 & 0.07 & -0.04 & 1.8 & 0.12 \\
\hline Voluntary disclosure1 & 0.0 & 0.79 & 0.48 & 0.19 & -0.71 & 2.45 & 0.03 \\
\hline Voluntary disclosure2 & 0.0 & 0.80 & 0.44 & 0.15 & -0.64 & 3.12 & 0.09 \\
\hline Total disclosure1 & 0.39 & 0.84 & 0.65 & 0.09 & -0.19 & 2.73 & 0.72 \\
\hline Total disclosure2 & 0.62 & 0.89 & 0.76 & 0.07 & -0.03 & 1.8 & 0.12 \\
\hline
\end{tabular}

S o u r c e : variables characteristics: the disclosure indices for the proposed method (method 1) are imported from Baazaoui et al. (2015).

It appears that the disclosure indices calculated according to the second method are higher than those calculated according to the first method and that disclosure indices of Canadian firms are higher than those of French firms. The gap is important for mandatory disclosure and full disclosure. According to the French sample, it reaches 0.08 for mandatory disclosure and 0.11 for total dis- 
closure. According to the Canadian sample, it reaches 0.09 for mandatory disclosure and 0.11 for total disclosure. According to the overall sample, it reaches 0.09 for mandatory disclosure and 0.11 for full disclosure. The voluntary disclosure index of the first method is higher than that of the second method. The difference between the voluntary disclosure indices is 0.02 for the French sample, 0.06 for the Canadian sample and 0.04 for overall sample.

To test the significance of the difference in disclosure indices, we use the parametric test difference of means for the variables that follow the normal law (voluntary disclosure (1.2) for Canadian sample and mandatory disclosure (1.2) and total disclosure (1.2) for overall sample) and the non-parametric test difference in medians (Wilcoxon test) for variables that do not follow the normal distribution.

The results of the statistical tests are as follows:

Table 4. Means (medians) equality

\begin{tabular}{|c|c|c|c|}
\hline Paires & Mean (Median) & T-test (Wilcoxon test) & Significance \\
\hline \multicolumn{4}{|l|}{ French sample } \\
\hline $\begin{array}{l}\text { Mandatory disclosure2-Mandatory } \\
\text { disclosure1 }\end{array}$ & $(0.71-0.64)$ & $(4.5)$ & 0.00 \\
\hline Total disclosure2-Total disclosure1 & $(0.70-0.59)$ & $(5.24)$ & 0.00 \\
\hline $\begin{array}{l}\text { Voluntary disclosure1-Voluntory disc- } \\
\text { losure2 }\end{array}$ & $0.39-0.37$ & 0.52 & 0.60 \\
\hline \multicolumn{4}{|l|}{ Canadian sample } \\
\hline $\begin{array}{l}\text { Mandatory disclosure2-Mandatory } \\
\text { disclosure1 }\end{array}$ & $0.81-0.72$ & 6.33 & 0.00 \\
\hline Total disclosure2-Total disclosure1 & $(0.81-0.69)$ & $(5.90)$ & 0.00 \\
\hline $\begin{array}{l}\text { Voluntary disclosure1-Voluntory disc- } \\
\text { losure2 }\end{array}$ & $(0.63-0.53)$ & $(2.83)$ & 0.03 \\
\hline \multicolumn{4}{|l|}{ Overall sample } \\
\hline $\begin{array}{l}\text { Mandatory disclosure2-Mandatory } \\
\text { disclosure1 }\end{array}$ & $0.77-0.68$ & 6.84 & 0.00 \\
\hline Total disclosure2-Total disclosure1 & $0.76-0.65$ & 8.37 & 0.00 \\
\hline $\begin{array}{l}\text { Voluntary disclosure1-Voluntory disc- } \\
\text { losure2 }\end{array}$ & $(0.50-0.47)$ & $(2.13)$ & 0.03 \\
\hline
\end{tabular}

S o u r c e : means (medians) equality: prepared in this paper. 
The different differences are statistically significant except to voluntary disclosure for French sample. Thus, the indices calculated according to the two methods are different and therefore the new method differs from the conventional method of calculating the disclosure index.

\section{IIICNCLUSION}

We have proposed a new method of calculating the disclosure index that consists of calculating the elementary disclosure index and averaging the elementary disclosure scores to determine the overall disclosure index. Thus, for mandatory disclosure, a basic disclosure score is calculated per accounting standard and for voluntary disclosure and in this study, an elementary score is calculated per accounting standard and for studies that use voluntary categories of information (information general, financial information, social information, environmental information, operational and strategic information, etc.), we propose to calculate the score by category of information and average these scores to determine the overall disclosure index.

\section{REFERENCES}

Alves, H.S., Canadas, N., \& Rodrigues, A.M. (2015). Voluntary disclosure, information asymmetry and the perception of governance quality: an analysis using a structural equation model. TÉKHNE - Review of Applied Management Studies, 13(1), 66-79. https://dx.doi.org/10.1016/j.tekhne.2015.10.001.

Avallone, F., \& Quagli, A. (2015). Insight into the variables used to manage the goodwill impairment test under IAS 36. Advances in Accounting, incorporating Advances in International Accounting, 31(1), 107-114. https://dx.doi.org/10.1016/j.adiac.2015.03.011.

Baazaoui, H., Sahnoun, M.H., \& Zaraï, M.A. (2015). Culture, Economics and Disclosure of (IAS/IFRS) Information: Empirical Evidence in the Tunisian, French and Canadian Contexts. Research Journal of Finance and Accounting, 6(6), 59-72.

Baik, B., Cho, H., Choi, W., \& Lee, K. (2016). Who classifies interest payments as financing activities? An analysis of classification shifting in the statement of cash flows at the adoption of IFRS. Journal of Accounting and Public Policy, 35(4), 331-351. https:// dx.doi.org/10.1016/j.jaccpubpol.2015.11.003.

Bamber, M., \& McMeeking, K. (2016). An examination of international accounting standard-setting due process and the implications for legitimacy. The British Accounting Review, 48(1), 59-73. https://dx.doi.org/10.1016/j.bar.2015.03.003. 
Barneto, P., \& Ouvrard, S. (2015). Is the firm's business model related to segment reporting? Run tries and the particular case of Zimbabwe. The International Journal of Accounting, 35(2), 267-286.

Cerbioni, F., Fabrizi, M., \& Parbonetti, A. (2015). Securitizations and the financial crisis: is accounting the missing link? Accounting Forum, 39(3), 155-175. https://dx.doi. org/10.1016/j.accfor.2014.05.001.

Chan, A.L-C., Hsieh, Y.-T., Lee, E., \& Yueh, M.-L. (2015). Does financial statement information affect cross-border lending by foreign banks in the syndicated loan market? Evidence from a natural experiment. Journal of Accounting and Public Policy, 34(5), 520-547. https://dx.doi.org/10.1016/j.jaccpubpol.2015.05.005.

Chen, L.H., Deng, S., Gupta, P.P., \& Sami, H. (2015). The SEC's elimination of 20-F reconciliation and information asymmetry. Journal of Contemporary Accounting \& Economics, 11(1), 75-87.

Churyk, N.T., Yu, S.C., Gross, G.M., \& Stoettner R. (2015). Johnson manufacturing case study -bankruptcy. Journal of Accounting Education, 33(4), 309-316.

De Simone, L. (2016). Does a common set of accounting standards affect tax-motivated income shifting for multinational firms? Journal of Accounting and Economics, 61(1), 145-165. https://dx.doi.org/10.1016/j.jacceco.2015.06.002.

Ding, Y., Jeanjean, T., \& Stolowy, H. (2005). Why do national GAAP differ from IAS? The role of culture. The International Journal of Accounting, 40(4), 325-350. https:// dx.doi.org/10.1016/j.intacc.2005.09.004.

Eiler, L.A., Miranda-Lopez, J., \& Tama-Sweet, I. (2015). The Impact of accounting disclosures and the regulatory environment on the information content of earnings announcements. The International Journal of Accounting, 50(2), 142-169. https:// dx.doi.org/10.1016/j.intacc.2012.10.008.

Ellwood, S., \& Greenwood, M. (2016). Accounting for heritage assets: does measuring economic value 'kill the cat'? Critical Perspectives on Accounting, 38, 1-13. https:// dx.doi.org/10.1016/j.cpa.2015.05.009.

Elshandidy, T., Fraser, I., \& Hussainey, K. (2015). What drives mandatory and voluntary risk reporting variations across Germany, UK and US? The British Accounting Review, 47(4), 376-394. https://dx.doi.org/10.1016/j.bar.2014.06.001.

Ghio, A., \& Verona, R. (2015). Accounting harmonization in the BRIC countries: a common path? Accounting Forum, 39(2), 121-139. https://dx.doi.org/10.1016/j.accfor.2015.02.001.

Joliet, R., \& Muller, A. (2016). Are foreign earnings disclosures value-relevant? Disaggregation solves the puzzle. Research in International Business and Finance, 37, 170183. https://dx.doi.org/10.1016/j.ribaf.2015.09.009.

Joseph, C., \& Taplin, R. (2011). The measurement of sustainability disclosure: abundance versus occurrence. Accounting Forum, 35(1), 19-31.

La Bruslerie, H., \& Gabteni, H. (2014). Voluntary disclosure of financial information by French firms: does the introduction of IFRS matter? Advances in Accounting, incorporating Advances in International Accounting, 30(2), 367-380. https://dx.doi. org/10.1016/j.adiac.2014.09.016. 
Lin, Y.-T., \& Nienhaus, M. (2015). The non-diversifiable risk of financial reporting system: evidence from the German market. Advances in Accounting, incorporating Advances in International Accounting, 31(2), 197-208. https://dx.doi.org/10.1016/j.adiac.2015.09.008.

Maroun, W., \& van Zijl, W. (2016). Isomorphism and resistance in implementing IFRS 10 and IFRS 12. The British Accounting Review, 48(2), 220-239. https://dx.doi. org/10.1016/j.bar.2015.07.003.

Nnadi, M., \& Soobaroyen, T. (2015). International financial reporting standards and foreign direct investment: The case of Africa. Advances in Accounting, incorporating Advances in International Accounting, 31(2), 228-238. https://dx.doi.org/10.1016/j.adiac.2015.09.007.

Palea, V. (2015). The political economy of fair value reporting and the governance of the standards-setting process: Critical issues and pitfalls from a continental European union perspective. Critical Perspectives on Accounting, 29(C), 1-15. https://dx.doi. org/10.1016/j.cpa.2014.10.004.

Păúcan, I.-D. (2015). Measuring the effects of IFRS adoption on accounting quality: a review. Procedia Economics and Finance, 32, 580-587. https://dx.doi.org/10.1016/ S2212-5671(15)01435-5.

Perera, D., \& Chand, P. (2015). Issues in the adoption of international financial reporting standards (IFRS) for small and medium-sized enterprises (SMES). Advances in Accounting, incorporating Advances in International Accounting, 31(1), 165-178. https://dx.doi.org/10.1016/j.adiac.2015.03.012.

Pierk, J., \& Weil, M. (2016). Price regulation and accounting choice. Journal of Accounting and Public Policy, 35(3), 256-275. https://dx.doi.org/10.1016/j.jaccpubpol.2015.12.005.

Street, D.L., \& Bryant, S.M. (2000). Disclosure level and compliance with IASs: a comparison of companies with and without U.S. listings and filings. The International Journal of Accounting, 35(3), 305-329. https://dx.doi.org/10.1016/S00207063(00)00060-1.

Teuteberg, T., Voll, D., \& Zülch, H. (2016). The success story of international additives producer AG: A case study on categorization of investments under IFRS. Journal of Accounting Education, 34, 13-29. https://dx.doi.org/10.1016/j.jaccedu.2015.11.003.

Uyar, A., \& Güngörmüs, A.H. (2013). Perceptions and knowledge of accounting professionals on IFRS for SMEs: Evidence from Turkey. Research in Accounting Regulation, 25(1), 77-87. https://dx.doi.org/10.1016/j.racreg.2012.11.001.

Verrecchia, R.E. (1983). Discretionary disclosure. Journal of Accounting and Economics, 5, 179-194. https://dx.doi.org/10.1016/0165-4101(83)90011-3.

Wilford, A.L. (2016). Internal control reporting and accounting standards: A crosscountry comparison. Journal of Accounting and Public Policy, 35 (3), 276-302. https://dx.doi.org/10.1016/j.jaccpubpol.2015.12.006.

Xiao, J.Z., Yang, H., \& Chow, C.W. (2004). The determinants and characteristics of voluntary Internet-based disclosures by listed Chinese companies. Journal of Accounting and Public Policy, 23(3), 191-225. 
Xiao, J.Z., Gao, S.S., Heravi, S., \& Cheung, Y.C.Q. (2005). The impact of social and economic development on corporate social and environmental disclosure in Hong Kong and the United Kingdom. Advances in International Accounting, 18, 219-243. https:// dx.doi.org/10.1016/S0897-3660(05)18011-8. 